\title{
Herczeg Bálint*
}

\section{A globalizáció hatása a monetáris politika transzmissziójára}

Jelen cikk célja, hogy megvizsgálja, a gazdasági globalizáció és a hajtóéröként mögötte álló technológiai fejlődés mikéntváltoztatja meg a monetáris transzmissziót. Azirodalomáttekintése után arra azeredményre jutunk, hogy ezt az egyébként is összetett kapcsolatot még a korábbiaknál is kiszámíthatatlanabbá teszi az integráció fokozódása, erősítve a kamatláb- és vagyonhatásokat, gyengítve a hitelcsatornát és árfolyamcsatornát, különösen ha a devizahitelek vagy a carry trade szerepe jelentős.'

Journal of Economic Literature (JEL) kód: E44, E52, F42

Kulcsszavak: monetáris transzmisszió, globalizáció

\section{Bevezetés}

A cikk célja, hogy megvizsgálja, miképpen változott a monetáris politika transzmissziója az új technológiai környezet hatására, beleértve az internet elterjedését és a részben a kommunikációs technológia változásával hajtott gazdasági integrációt, azaz a globalizációt.

A transzmissziós mechanizmusok ismerete elengedhetetlenül szükséges a sikeres monetáris politikához. Minden központi banknak tudnia kell, hogy az általa indított monetáris sokk milyen időzítéssel és milyen erővel hat a gazdaság különböző változóira, milyen módon, „útvonalon” keresztül tudja a célváltozót befolyásolni. Kézenfekvőnek tünik, hogy ha valami megváltozik ebben a folyamatban, akkor a monetáris politikát is felül kell vizsgálni, hiszen ugyanahhoz a célhoz már más erősségü és időtartamú lépések lennének szükségesek. A fokozódó gazdasági integráció általánosságban annyira megváltoztatta a gazdasági kapcsolatokat, hogy a transzmisszióban szereplő kapcsolatokra is hatott. „A monetáris politika biztosan nem maradt immunis.” (Bollard 2007:1). Valószínüleg nem is az az igazi kérdés, hogy megváltozott-e a transzmisszió a globalizáció következtében, hanem hogy mennyire és milyen irányba (gyengült vagy erösödött, gyorsult vagy lassult).

Az irodalom áttekintéséből azt a következtetést lehet levonni, hogy a változások a monetáris politika transzmisszióját még kiszámíthatatlanabbá tették, a transzmisszió bizonyos csatornáit erősítették, más csatornákat pedig gyengítettek. A fokozódó bizonytalanság kezelésének egyik lehetséges módja, hogy sokkal óvatosabb, fokozatosabb lépéseket

\footnotetext{
* Herczeg Bálint doktorandusz hallgató a Debreceni Egyetem Közgazdaságtudományi Karán, e-mail: balint.herczeg@ gmail.com.

1 A tanulmány az Innováció és intézményrendszer - a múlt tanulságai és a jelen kihívásai címü Jedlik Ányos Pályázat keretében készült (OM-00019/2007. számú szerződés).
} 
tesznek a döntéshozók, ami ugyan megvédi őket nagy hibák elkövetésétől, de egyben az elmúlt időszak hibáinak hatását is elnyújtja.

A cikk felépítése a következő: először röviden áttekintjük a monetáris politika transzmissziós mechanizmusait, ezt követően pedig külön megvizsgáljuk, hogy a folyamat egyes szakaszait miképpen befolyásolja a környezet megváltozása. Majd pedig a különböző transzmissziós csatornák változásainak áttekintésénél ismét összerakjuk az egész folyamat különböző részeinek változásait. Az utolsó részben összefoglaljuk az elmondottakat.

\section{Monetáris transzmisszió}

Ahhoz, hogy megérthessük a monetáris politika transzmisszióját, a monetáris politika szerepével és módszereivel kell kezdeni a sort. A monetáris politika módszerei sokat változtak az utóbbi évtizedekben, Mishkin (2007b) szerint előnyére, hiszen a monetáris politika egyre tudományosabban bizonyított kapcsolatokon alapul, és bár továbbra is szükség van bizonyos esetekben szakértői véleményekre, az utóbbi évtizedben nagyobb lépéseket tett a tudományos megközelítés irányába, mint korábban bármikor. Az alapokat jelentő, bizonyított összefüggések a következők. ${ }^{2}$

- Mivel az árstabilitás önmagában is értéket képvisel, ${ }^{3}$ és az infláció monetáris jelenség, ezért a monetáris politika céljának mindig az árstabilitás fenntartásra kell irányulnia. Ehhez viszont fontos kérdés az árstabilitás definíciója. Blinder (2006) többekkel összhangban kifejti, hogy a $2 \%$-os infláció egyrészt elég magas ahhoz, hogy védjen a CPI felfelé torzítása ellen, másrészt viszont mégis elég alacsony ahhoz, hogy minimalizálja az infláció költségeit. Szerinte érdemes lenne a $2 \%$-ot valamilyen maginflációs indexszel mérni, mivel azt könnyebb a központi bankoknak elöre jelezni és befolyásolni. Kommunikációs okok miatt a központi bankok gyakran mégis a teljes inflációs mutatót segítségével határozzák meg az árstabilitást. Ennek az a kockázata, hogy monetáris politika olyan sokkok miatt véti el a célját (lásd például olajársokk), amit nem tud igazából befolyásolni, így a szigorítások miatt előfordulhat, hogy a szükségesnél nagyobb kibocsátási veszteséget okoz.

- A várakozásoknak nagyon jelentős szerepük van az inflációs folyamatban, a (majdnem) racionális várakozások teszik függőlegessé a hosszú távú Phillips-görbét. Ez összhangban van a reál- és nominális változók hosszú távú függetlenségével (klasszikus dichotómia).

- A gazdaságpolitikai szabályok fontos szerepet játszanak az időinkonzisztenciaproblémák elkerülésében. Itt a Taylor-szabályt (Taylor 1993) érdemes megemlíteni, amely szerint a monetáris politikának az inflációs sokknál nagyobb mértékben kell emelnie a kamatokat az árstabilitás eléréséhez. A modellekbe leggyakrabban veszteségfüggvényként építik be a szabályokat, ahol az inflációs céltól való eltérésén túl a reálváltozók variabilitása is veszteséget okoz a monetáris politikának. Ennek egyrészt az az oka, hogy a reálváltozók hosszú távú egyensúlyi értéktől való eltérése jövőbeli inflációs nyomást jelent, másrészt

2 Hasonló alapösszefüggések találhatók Mishkin (2000)-ben, de eltérö csoportosításban.

${ }^{3}$ Az infláció hagyományosnak tekinthetö költségeiröl lásd Briault (1995) összefoglalóját, amelyet English (1999) kiegészít egy további költséggel, amely szerint a magasabb infláció túlberuházást okoz a pénzügyi szektorba, ami nem hatékony allokáció, tehát veszteségnek számít. 
viszont a monetáris politikának az áldozati rátát is figyelembe kell vennie (Issing et al. (2005) alapján még hitelesebb és ez által sikeresebb az árstabilitás melletti elkötelezettség akkor, ha a monetáris politika azt ígéri, hogy lépései során nem fogja figyelembe venni a reálveszteségeket). Blinder (2006) által megfogalmazott kérdésre, hogy a munkanélküliség vagy a kibocsátás kerüljön-e be a veszteségfüggvénybe, később még visszatérünk.

- A gazdaságpolitikai szabályokon túl a hitelesség segíthet az időinkonzisztenciaproblémák elkerülésében. A hitelesség elérésének egyik módja a függetlenség megszerzése, ${ }^{4}$ ami egy demokratikus berendezkedésü országban csak eszközfüggetlenséget jelenthet (azaz szabadon megválaszthatja célja elérésének eszközét), és nem célfüggetlenséget, mivel a monetáris politika döntéshozó testületébe nem választás útján kerülnek személyek, így nincs felhatalmazásuk arra, hogy saját célt határozzanak meg. A monetáris politika célját ezért legtöbbször a kormányzattal közösen határozzák meg, aminek meglehet az az árnyoldala, hogy esetleg politikai okokból akarják a célt megváltoztatni, ami ismét relevánssá teszi az időinkonzisztencia-problémát (Mishkin 2000).

- Egy nominális horgony hasznos a várakozások lehorgonyzásában, ami azt jelenti, hogy egyszerü, könnyen érthető kapcsolatban kell állnia az árstabilitással. ${ }^{5}$ Ahogy korábban már említettük, a legtöbb ország éppen a nominális horgony jellege miatt a teljes (headline) inflációban határozza meg az árstabilitást, még ha technikai okok miatt jobb lenne valamilyen maginflációval definiálni.

- Mishkin (2007b) felsorolásában az utolsó fontos összefüggés, hogy a monetáris politikának figyelnie kell a pénzügyi közvetítö rendszer stabilitására, mert az üzleti ciklusok és a pénzügyi válságok erösen korrelálnak. Éppen ezért javasolja Blinder (2006), hogy a kamatlábak volatilitásán keresztül be kellene építeni közvetlenül a veszteségfüggvénybe, azaz a monetáris politika reakciószabályába a közvetítő rendszer állapotát. Az e kérdés körül kialakult vitára már csak az aktualitása miatt is visszatérünk.

Ezeken az empirikusan bizonyított tényeken és kapcsolatokon túl a politikai döntéshozóknak még mindig támaszkodniuk kell a szakmai tapasztalataikra, véleményükre, megítélésükre. Főleg olyan esetekben, ahol az adat hiánya vagy jellege miatt nem lehet kifinomultabb módszereket használni, vagy strukturális törések növelik a bizonytalanságot. A monetáris politikai döntések meghozatala Mishkin (2007b) szerint a fentiek ellenére részben még mindig müvészet. ${ }^{6}$

Ezen összefüggések figyelembevételével a monetáris politika transzmissziós folyamatát a következőképpen lehetne felvázolni:

- a monetáris politika döntéshozó testülete a céljainak megfelelően beállítja az eszközváltozó értékét (a döntés során figyelembe veszik a fenti bizonyított tényeket és a saját tapasztalataikat is - lásd korábban). Ez egy inflációs célkövetési rendszerben azt jelentené, hogy ha a bank által elöre jelzett infláció eltérne az inflációs célértékétől, akkor a testület megváltoztatná az eszközként használt kamatlábat;

- az eszközváltozó megváltozása hatással van a pénzügyi eszközök áraira és likviditására (részben direkt úton, részben pedig a várakozások befolyásolásán keresztül);

${ }^{4}$ Cukierman (2007) megmutatja, hogy a függetlenség önmagában is alacsonyabb és stabilabb inflációt eredményez.

${ }^{5}$ Bernanke (2005) szerint a fix árfolyamok legfontosabb szerepe, hogy nagyon egyértelmü nominális horgonyként müködhet.

${ }^{6}$ Issing et al. (2005)-nél hasonló „munkamegosztást" találhatunk a monetáris politika tudománya és a művészete között. 
- a pénzügyi környezet megváltozása befolyásolja a vállalatok és a háztartások döntéseit és választási lehetőségeit - ezzel pedig a gazdaság keresleti oldalát;

- a megváltozott keresleti oldal hatással van az infláció dinamikájára.

Egy egyszerü ábrával (1. ábra) a következőképpen lehetne a fenti összefüggéseket felvázolni:

\section{A monetáris transzmisszió váza}

1. ábra

\section{cél $\Rightarrow$ eszköz változó ára $\Rightarrow$ többi pénzügyi eszköz $\Rightarrow$ háztartások és vállalatok viselkedése (aggregált kereslet) $\Rightarrow$ infláció dinamikája}

Attól függően, hogy a monetáris politika eszközváltozója milyen eszközök árait árazza át, és azok a szereplők viselkedését milyen módon befolyásolják, különböző transzmissziós csatornákat különböztet meg a szakirodalom: ${ }^{7}$

- az árfolyamcsatorna a külső kereslet és kínálat változásain vagy a vagyonelemek átárazódásán keresztül hat;

- a kamatcsatornán keresztül a monetáris politika az alternatívaköltségen keresztül befolyásolni tudja a vállalatok beruházásait és a háztartások fogyasztását (helyettesitési hatás) ${ }^{8}$

- a vagyoncsatornák esetében a kamatláb a diszkontfaktoron keresztül változtatja meg a vagyonelemek értékét, aminek lehet direkt hatása a háztartások fogyasztására a vagyoni helyzet megváltozásán keresztül (vagyonhatás), vagy pedig kamatjövedelmük és így a rendelkezésre álló jövedelmük változásán keresztül (jövedelmi hatás). Hasonló mechanizmusokat lehetne a vállalatokra is megfogalmazni; ${ }^{9}$

- a hitelcsatornák az eddigi csatornák kiegészítöi, mivel a monetáris impulzus felerősíti a pénzügyi rendszerben meglévő aszimmetrikus információs problémákat. A pénzügyi eszközök értékének monetáris politika okozta csökkenése miatt kisebb fedezetet nyújthatnak a hitelekhez (mérleghatás), ez pedig megakadályozhatja a vállalatokat a beruházások külső finanszírozásában, vagy a háztartásokat abban, hogy simítsák fogyasztásukat. A súrlódások megakadályozhatják, hogy egyes bankok refinanszírozási hiteleket kapjanak a központi banktól (bankhitelezési csatorna), emiatt csökkenteniük kell a hitelkihelyezésüket. Ahhoz hogy ez a csatorna erösen hasson, az szükséges, hogy a bankok kicsik legyenek és így központi bank finanszírozására legyenek utalva, a vállalatok esetében pedig, hogy korlátozottak legyenek a lehetőségeik a banki hitelek tőkepiaci forrásokkal történő helyettesítésére; ${ }^{10}$

- a várakozási csatorna múködése a monetáris politika hiteles kommunikációjától függ, mivel képes befolyásolni a szereplők viselkedését várakozásaik és a jövőre vonatkozó döntéseik befolyásolásán keresztül.

A követkő fejezetekben áttekintjük, hogy a megváltozott technikai környezet és a felerösödött integrációs folyamatok hogyan módosítják a fenti mechanizmusokat. Alapvetően az

\footnotetext{
${ }^{7}$ Az itt felvázolt transzmissziós csatornákról bővebb összefoglalót ad Mishkin (1996).

${ }^{8}$ Lásd bővebben Taylor (1995).

9 Ide lehetne sorolni a Tobin-féle q-hatást (Tobin 1969).

10 E csatorna klasszikus forrása Bernanke - Gertler (1995), míg Bernanke (2007) összefoglalja a legújabb irodalmat.
} 
1. ábra négy nyilából az utolsó három nyíllal foglalkozunk. Az első nyíl azért marad ki, mert az maga a monetáris politikai döntés, amire már röviden kitértünk az előzőekben (a bizonyított alapelvek mind erre vonatkoztak), és a cikknek nem célja, hogy a fenti áttekintésnél e témával bővebben foglalkozzon.

\section{A technológia és a globalizáció hatása a monetáris transzmisszióra}

A pénzügyi piacok integrációja az egyik elsődleges forrása azoknak a változásoknak, amelyek a monetáris transzmissziót befolyásolhatják. Gudmundsson (2008:9)-t követve, a teljesen integrálódott piacot úgy definiálhatjuk, ahol minden szereplő számára ugyanazon szabályok érvényesek, egyenlő hozzáférésük van és egyenlően bánnak velük. Különböző súrlódások (tranzakciós költségek, aszimmetrikus információk stb.), az egy ár törvénye legtöbbször mégsem figyelhető meg, annak ellenére, hogy a globálisan integrálódott piacok az egész világra kiterjednek.

Genberg (2008) szerint az integrációt a törvénykezés (liberalizáció, kamatláb-dereguláció), a technológia, a gazdaság elmélet és a monetáris stratégia (itt elsősorban az árfolyamrezsimek változásait emeli ki) változásai mozgatják. A következőben elsősorban a technológiai fejlődés hatásait vizsgáljuk.

Elsőként megnézzük, hogy a technológiai fejlődés milyen módon befolyásolja, hogy a pénzügyi közvetítés el tudja látni a feladatát. Mishkin - Strahan (1999) érvelésének középpontjában az aszimmetrikus információs problémák kezelésének változása áll. A pénzügyi közvetítő rendszer azért jött létre, hogy azokat a költségeket, amelyeket ezek a problémák okoznak, csökkentsék, tehát ha az új technológiai környezet új lehetőségeket biztosít a problémák kezelésére, akkor a közvetítő rendszer maga is megváltozhat.

Az ebben az esetben jellemző aszimmetrikus információs problémák:

- kontraszelekció - azaz csak azok hajlandók magas kamatokat fizetni a hitelért, akik úgy érzik, hogy a magas kockázatok miatt valószínüleg nem fogják visszafizetni - különféle biztosítékok segíthetnek a hitelfelvevő visszafizetésre ösztönzésében,

- erkölcsi kockázat - a hitel felvétele után az adós ösztönözve érezheti magát arra, hogy pluszkockázatokat vállaljon, hiszen az ebből származó pluszbevétel a sajátja, a bukással járó kockázat pedig a hitelezőt terheli,

- monitoring - ez jelenthetne megoldást az erkölcsi kockázat problémájára, de mivel ez közjószág, felmerül potyautas-probléma, azaz ha egy bank megfigyeli az ügyfél viselkedését, akkor a többi hitelező már „potyázhat”, vagyis a költséges megfigyelés nélkül is nyújthat hitelt az adott ügyfélnek.

Milyen új megoldásokat tesz lehetővé az új technológia?

Egyrészt új módszerek (pl. scoring módszer) segítenek a kontraszelekció és az erkölcsi kockázat okozta problémák enyhítésében, aminek okán minden szektorban emelkedett a hitelek mennyisége (kis- és középvállalkozások, háztartások) (Mishkin - Strahan 1999). Másrészt a standardizált hitelek könnyebben áttekinthetők, így ezeket egyszerübben lehet értékpapírosítani. A derivatívok a kockázatok kezelését és elosztását teszik lehetővé. A fizetési rendszer változásai (internetbanking vagy ATM) pedig könnyebb hozzáférést és a földrajzi különbségek csökkenését eredményezik.

E változások eredményeként a pénzügyi intézmények már nem csak egyszerü betéteket kínálnak az ügyfeleiknek, hanem jól diverzifikált portfóliókat. A bankrendszer konszolidációja is kapcsolatba hozható ezzel a folyamattal, hiszen a scoring modellek mögötti 
módszertan kidolgozása és az elektronikus szolgáltatásokhoz szükséges infrastruktúra kiépítése megnöveli a hatékony bankméretet. Az új módszerekkel egy nagybank helyi fiókja is majdnem ugyanolyan jól tud hitelek nyújtani kis helyi cégeknek, mint egy helyi kisbank. A konszolidáció megnöveli a bankok lobbierejét is, ami segít felhívni a törvényhozás figyelmét a szektor szükségleteire. Ezzel együtt a versenyhelyzetet is megváltoztatja, különös tekintettel a piac földrajzi kiterjedésére (pl. egy kis külvárosi bank is versenyezhet a belvárosi bankokkal néhány jól elhelyezett atm és az internetes banki szolgáltatások segítségével) - ami versenyszabályozási kérdéseket is felvethet.

Genberg (2008) szerint már nincs értelme a pénzügyi intézményrendszer bankközpontú és tőkepiac-központú felosztásának, sokkal inkább érdemes kapcsolatalapú (amikor hosszú távú kapcsolatban az ügyfél privát információkat oszt meg a kölcsönadóval) és a három lépés távolságú (nyilvános információkon alapuló) közvetítésről beszélni. Ebből a nézőpontból a legnagyobb változás a pénzügyi intézményrendszerben a kapcsolatalapú közvetítés jelentőségének csökkenése, a korábban egymástól elválasztott/szeparált piacok integrálódása és a vállalatok tőkeszerzési lehetőségeinek robbanásszerü növekedése.

Bordo et al. (1999) arra a következtetésre jutnak, hogy az integráció mai mértéke példa nélküli a történelemben, sokkal mélyebb és a világ több régiójára kiterjed, mint bármikor korábban. Hasonló eredményre jut Obstfeld - Taylor (2002) is, miközben a pénzügyi integráció négy lehetséges mutatójának időbeli alakulását vizsgálják. A tőke mennyisége, a reál-, kötvény- és részvényhozamok együttmozgása és a fedezetlen kamatparitás teljesülése időben $U$ alakot formáz 1870 és 2002 között. Az integráció alakulásának „alakját” Obstfeld - Taylor (2002) szerint elsősorban a különböző akadályok (kereskedelmi és tőkepiaci) befolyásolták és nem a gazdaság struktúrájának megváltozása (ha a technológia lenne a legfontosabb meghatározó, akkor folyamatosan erősödő integráció lenne megfigyelhető). Ehrmann - Fratzscher (2006) a Federal Open Market Committee (FOMC)-találkozókat követő 30 percben mérik a bejelentés okozta sokk erősségét a világ 50 részvényindexére, és ennek a transzmissziónak az erősségével jellemzik az integráció mértékét. Eredményeik szerint a sokk transzmisszióját sokkal jobban befolyásolja a pénzpiac nyitottsága és az adott index összetétele, mint a bejelentett árfolyamrezsim. Feldstein (2005) a Feldstein - Horioka (1980)-ban ismertetett módszerrel mutatja be az integráció változását. Az eredeti, 1980-as eredmény szerint a tőkepiacok szegmentáltak voltak, mivel a megtakarítások $80 \%$-át abban az országban fektették be, ahol maga a megtakarítás keletkezett. Az új eredmények szerint a szegmentáció mértéke csökkent, de az otthon történő befektetés (home bias) még mindig megfigyelhető a nagy ipari országoknál, miközben a kis, nyitott országok sokkal integráltabbá váltak a tőkepiacokban.

Mivel a különböző krízisek és kereskedelmi feszültségek együtt járnak a nagyobb integrációval (1914 elött is megfigyelhető volt), az igazán érdekes kérdés az, hogy a nagyobb mértékü integráció miért nem okoz nagyobb feszültséget napjainkban. Bordo et al. (1999) szerint annak az okai, hogy manapság az integráció előnyei sokkal több embert érintenek, mint korábban, két nagy csoportba sorolhatók. Egyrészt a jobb információáramlás és a jobb intézményi háttér (például fejlettebb számviteli standardok) miatt könnyebb kezelni az aszimmetrikus információs problémákat, és ritkábban következnek be pénzügyi válságok (bár azt is meg kell jegyezni, hogy ha viszont bekövetkezik, az egyszerre érint mindenkit - hiszen az integráció következtében nemcsak a tőke mozog egyre könnyebben, hanem a sokkok hatásai is szabadon terjednek). Másrészt az intézmények jobb minősége (szociális háló) és a derivatívok által lehetővé tett kockázatmegosztás védelmet nyújthat a krízisek 
elmélyülése ellen. Obstfeld - Taylor (2002) is ebben látják a legnagyobb különbséget az 1914 elötti és a mostani integráció között: a mai integráció hajtóereje a diverzifikáció, ami abban is megmutatkozik, hogy az Egyesült Államok a legnagyobb adós és legnagyobb eszköztulajdonos egyszerre, míg ezzel ellentétben 1914 előtt a fejlesztő tőkeáramlás (development finance) volt inkább jellemzö, ahol elvált egymástól a kölcsönadó és az adós szerepköre.

Egy másik jelenség, ami összefügg(het) az integrációval és fontos a monetáris politika transzmissziójának szempontjából is, az a kibocsátás volatilitásának csökkenése.

Stock - Watson (2003) eredményei alapján a G7-országok kibocsátásának varianciája 1984 és 2003 között csak 50-80 százaléka volt az 1960-1983 közöttinek, ami még akkor is figyelemre méltó, ha valószínűleg a különböző országoknál már töréspontot kellene keresni, és trendváltozások kiszürése is befolyásolhatja a kapott eredményeket. De mi okozhatta ezt a stabilitást? Egyik lehetőség, hogy a jobb minőségű monetáris politika eredményeként létrejött alacsonyabb és stabilabb infláció áll a stabilabb kibocsátás hátterében. Ez a magyarázat önmagában nem elégséges, mivel ha szigorúbb antiinflációs, az 1984-2003 közötti periódusra becsült monetáris politikai szabályokkal szimulálták az 1960-1983 közötti folyamatokat, akkor bár tényleg alacsonyabb kibocsátásvolatilitást kaptak eredményül, de a modellből kapott csökkenés nagyságrendje jelentösen kisebb volt, mint az adatokban megfigyelt csökkenés. A másik magyarázat lehet a gazdaság struktúrájának megváltozása: az új technológia elterjedése rugalmasabbá teheti a termelést (kisebb készletek, részfoglalkoztatás elterjedése), a pénzügyi integráció pedig szélesítheti azoknak a forrásoknak a körét, amelyet a háztartások fogyasztásuk simítására alkalmazhatnak (ezt a magyarázatot támogatja Cecchetti 2002). Ezt az elképzelést cáfolja Kose et al. (2006): eszerint a fogyasztás volatilitása relatíve növekedett a kibocsátás volatilitásához képest, és az irodalom áttekintése után arra a következtetésre jut, hogy nincs szisztematikus kapcsolat a pénzügyi integráció és a kibocsátás volatilitása között (Kose et al. 2006:17). ${ }^{11}$ További magyarázatot jelenthet, ha megváltozott a gazdaság szektorális összetétele, ekkor ugyanis a kevésbé volatilis szektorok (szolgáltatások) súlyának növekedése és a volatilisabb szektorok (tartós fogyasztási cikkek vásárlása) súlyának csökkenése stabilizálóan hathat a kibocsátásra. Stock - Watson (2003) e magyarázatokat azért veti el, mert a szektorális összetétel megváltozása vagy a termelés rugalmasabbá válása hosszú folyamat, ami már a 40-es évek óta tart, így a volatilitás csökkenésének is folyamatosnak kellett volna lennie, nem pedig szakadásszerünek. A többi magyarázat kizárása után a szerzőpáros arra a megállapításra jut, hogy a választ kisebb külső sokkokban kell keresni, tehát a megfigyelt jelenség véletlen és ebből következően átmeneti.

A következőkben az vizsgáljuk, hogy az új környezetnek milyen hatása lehet az 1.ábrán szereplő „nyilakra”, azaz az eszközváltozó és a többi pénzügyi eszköz ára, az eszközárak és aggregált kereslet, valamint az aggregált kereslet és az infláció közötti kapcsolatra.

11 Bővebben lásd Kose et al. (2006) részletes áttekintését a pénzügyi integráció és a növekedés kapcsolatát vizsgáló irodalomról. Ennek során arra a megállapításra jutnak, hogy "ha a pénzügyi integrációnak pozitív hatása van is a növekedésre, akkor úgy néz ki, hogy az a hatás nem robusztus, ha a növekedést befolyásoló szokásos tényezőket kontrolláljuk" (Kose et al. 2006:13), és inkább a járulékos elönyök (collateral benefits) jelenlétére keresnek empirikus bizonyítékokat, azaz a nyitottság okozta intézményi változásokra. Később, az inflációs ösztönzőknél mi is kitérünk erre. 


\section{Megváltozott környezeti hatás a monetáris politika eszközváltozója és a piaci eszközárak közötti kapcsolatra.}

$\mathrm{Az}$ 1. ábra első nyila az úgynevezett kamatátgyürüzés (interest rate pass-through), azaz annak a mértéke, hogy a monetáris politika által meghatározott központi kamatláb milyen mértékben befolyásolja a piaci kamatlábakat és az egyéb eszközárakat.

Freedman (2000) és Friedman (1999) is arra a kérdésre keresik a választ, hogyan képes a központi bank a piac méreteihez képest kicsi intervenciókkal, nyílt piaci müveletekkel befolyásolni a piaci kamatlábat. Válaszuk szerint a meghatározó mozzanat az, hogy a jegybanknak monopóliuma van a tartalék képzésében. De a monopóliumon keresztül csak addig lehet az árakat befolyásolni, amíg a termék nehezen helyettesíthető, azaz amíg kereslet van a tartalékok iránt, azaz amíg:

- a háztartásoknak szükségük van készpénzre a tranzakciók lebonyolításához - ezt a feltételt gyengítik a különböző pénzhelyettesítők, ${ }^{12}$ amelyek eddig csak a fizetőeszközszerepkörben helyettesítették a jegybank által teremtett pénzt, de a jövőben az elszámolási eszköz szerepét is átvehetik, amivel kiszámíthatatlanná tehetik a pénzkeresletet. Ez még akkor is problémát jelent, ${ }^{13}$ ha a pénzkereslet nem tünik el teljesen, ami azért valószínü, hiszen a kormányzat nem mondana le a seigniorage jövedelméröl, azaz törvényhozási hatalmával élve elő fogja írni, hogy bizonyos tranzakciókat - mint az adók befizetése vagy a transzferek kifizetése - ezzel bonyolítsanak le;

- a bankok csak tartalékkal fedezett kötelezettséget bocsáthatnak ki - ez a feltétel is sérül egy olyan világban, ahol a kötelezettségek nagy része nem banki közvetítőktől származik (biztosítók és nyugdíjpénztárak, amelyek nincsenek tartalékolásra kötelezve), továbbá az értékpapírosítás esetén sem kell tartalékot képezni;

- tartalékokra van szükség a klíringrendszer müködtetéséhez - de nincs szükség hivatalos tartalékokra egy olyan klíringrendszerben, amely nem a jegybank körül szervezödik (pl. Clearing House Interbank Payments System - CHIPS - egy privát klíringrendszer, amely $96 \%$-os piaci részesedéssel rendelkezik a nagy összegü dollárátutalásoknál);

- alacsony a helyettesíthetőség a nemzeti valuták között - ez a feltétel sem érvényes, hiszen egyre nagyobb a helyettesíthetőség, egyre könnyebb idegen valutában eladósodni (pl. carry trade).

Weber (2007) szerint az átláthatóság, függetlenség és hitelesség sokkal fontosabb a várakozások lehorgonyzásához, mint az, hogy a jegybank képes-e befolyásolni a hosszú távú kamatokat, de hogy lehetne egy elköteleződés hiteles anélkül, hogy a bank képes lenne befolyásolni a célváltozóját. Ahogy korábban is említettük, a fenti folyamatok nagy valószínüséggel nem fogják megszüntetni a jegybank által teremtett tartalékok iránti keresletet, de a jegybanki kamatláb és a piaci eszközárak közötti kapcsolatot mégis bizonytalanabbá tehetik, ami azt jelenti, hogy a jegybank „lekapcsolódhat”14 a gazdaságról.

Gudmundsson (2008) szerint a pénzügyi közvetítés mélyülése (ha minden szükséges intézményi háttér adva van) önmagában elegendő ahhoz, hogy megkönnyítse a jegybanknak

12 Freedman (2000) csoportosítása a könnyebb hozzáférést biztosító eszközöket (atm), a tárolt értéket hordozó kártyákat (stored value card) és a különböző hálózati pénzeket sorolja az elektronikus pénzek közé.

13 Haydar - Seyfettin (2006) készpénz nélküli világot vizionálnak, amely víziót Friedman (2000) nagyon hevesen támad. Blinder (2000) felveti azt a további problémát is, hogy egy cashless-világban a központi bank külső finanszírozásra szorulna, ami viszont veszélyeztetné a függetlenségét.

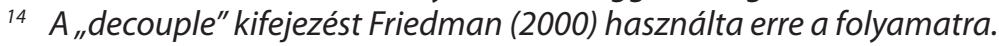


a rövid távú kamatok befolyásolását. A hosszú távú kamatlábakat egy kis nyitott országban ezzel szemben inkább a globális várakozások és faktorok befolyásolják, így itt megint nem lehet megállapítani, hogy mi a hatások eredője (további bizonytalanság). „Még ha úgy is tünik, hogy a kamatcsatorna gyengül, akkor sem nyilváníthatjuk még halottnak.” (Gudmundsson 2008:23)

Sukudhew et al. (2008) empirikus eredményei szerint a kamatátgyürüzés valóban erősebb a fejlettebb pénzügyi rendszerrel rendelkező országokban (tehát ahol nagyobb a verseny a pénzügyi piacon, szélesebbek és mélyebbek a kötvény- és részvénypiacok). Az erősebb azt jelenti, hogy gyorsabb az alkalmazkodás, és egy monetáris politika által indított kamatsokknak nagyobb az azonnali és a hosszú távú átgyürüzése. Módszerük egyik különlegessége, hogy az átgyürüzést nemcsak a banki kamatokra vizsgálták, hanem a hosszú távú piaci kamatokra is.

Weber (2007) szerint a részben gyengülő kamatcsatornát kompenzálja a feltehetően erösödő árfolyamcsatorna (ha csak Mundellből indulunk ki, rugalmas árfolyam mellett a monetáris politika annál hatékonyabb, minél szabadabban mozog a tőke). Ezzel vitatkozva Gudmundsson (2008) rámutat, hogy az árfolyam kettős jellege - azaz egyrészt egy fontos relatív ár, másrészt pedig egy pénzügyi eszköz - kiszámíthatatlanná teszi az árfolyam viselkedését és ezzel magát az árfolyamcsatornát is.

Összefoglalva az elmondottakat: mivel egyre inkább nő a jegybank által teremtett pénz helyettesíthetősége, ezért felmerül egy bizonyos fokú bizonytalanság az eszközkamatláb és a rövid távú kamatláb együttmozgásával kapcsolatban, de itt még - különösen a fejlett pénzügyi piacok esetében - erős átgyürüzést lehet megfigyelni. Ezzel szemben a hosszú távú kamatok esetében nagyobb a bizonytalanság és gyengébb az együttmozgás.

\section{Megváltozott környezeti hatás a piaci eszközárak és aggregált kereslet közötti kapcsolatra.}

Egyrészt Mylonas et al. (2000) szerint a mélyülő integráció miatt megnövekedett pénzügyi vagyon erősíti a vagyonon keresztül ható transzmissziós csatornákat, ezért az aggregált kereslet érzékenyebben reagálhat egy monetáris politika által okozott sokkra. Másrészt Wagner - Berger (2003) bemutatja, hogy az integráció volatilisabb eszközárakat eredményez. Érvelésük szerint mivel egyre több a befektetési lehetőség, és a fundamentumokról egyre zajosabb jelzéseket lehet szerezni, ezért egyre költségesebb hozzájutni a döntésekhez szükséges információkhoz. Tökéletesen racionális viselkedés ilyen helyzetben, ha a befektető egy olyan másik befektető viselkedését kezdi el másolni, akiről feltételezi, hogy megfelelő információkkal rendelkezik. Az ehhez hasonló nyájhatás- viselkedés viszont volatilitást eredményez, és gyakran buborékok kialakulásához vezet. A Mylonas et al. (2000) által kimutatott nagyobb vagyontömegnek (figyelembe véve annak nagyobb hatását a keresletre) a volatilisebb eszközárakkal együtt kiszámíthatatlanná, volatilisebbé kellene tennie az aggregált keresletet (Wagner 2002). Természetesen az is lehetséges, hogy fokozott eszközármozgásokra nem reagál az aggregált kereslet, hiszen a gazdasági szereplők nem tekintik permanens jövedelmükben bekövetkezett változásnak vagyonuk átárazódását, így nem reagálnak rá.

A volatilis eszközáraknál ki kell térni a pénzügyi rendszer stabilitásának korábban említett kérdésére, ami kiemelt jelentőségü, mivel ez a monetáris politika impulzusait közvetítő legfontosabb közeg, azaz csak akkor lehet a monetáris stabilitást fenntartani, ha a 
pénzügyi rendszer eléggé „egészséges” ahhoz, hogy közvetítse a monetáris politika jelzéseit (Weber 2007:4). Ez a probléma felveti a kérdést, hogy a monetáris politika megpróbálja-e csökkenteni az eszközárak volatilitását vagy esetleg még idejében leereszteni a kialakuló piaci buborékokat. Ennek az lenne az előnye, hogy ha a buborékok maguktól durrannak ki, akkor a pénzpiaci következményeket (csődök, zuhanó eszközárak) a különböző vagyonés hitelcsatornák tovább erősíthetik, ami nagy valószínüséggel recesszióhoz vezet. A megnövekedett integráció pedig növeli a fertőzés esélyét. Egy ilyen esemény hatására, a kármentés közben a monetáris stabilitás háttérbe szorulhat, a jegybank jelzéseit elnyomja a „csatazaj”. A kívánatos hatások ellenére felmerül egy valós probléma, hiszen ahhoz, hogy le lehessen ereszteni a pénzpiaci lufit, elöször azt kellene tudni, hogy az árak elrugaszkodtak-e a fundamentumok által meghatározott értékektől. Azaz a jegybanknak ismernie kellene a fundamentumokból következő eszközárat. Bernanke - Gertler (1999) szerint a jegybank elkerülheti ezt a kényes feladatot, ha az eszközárak változására csak abban a mértékben reagál, amennyi információt az infláció változásával kapcsolatban tartalmaz (azaz az inflációs célkövetési rendszerben az elörejelzéshez fontos információkat adó része lenne). Így az árat és a pénzügyi stabilitást is az inflációs célkövetési rendszeren belül lehetne és kellene kezelni. ${ }^{15}$

\section{Megváltozott környezet hatás a hazai aggregált kereslet és a hazai infláció közötti kapcsolatra.}

Mishkin (2007a) a következő változásokat gyüjtötte össze az infláció dinamikájának megváltozásával kapcsolatban:

- az infláció perzisztenciája megnövekedett, azaz a rövid távú sokkok kisebb hatással vannak az infláció trendjére,

- a rövid távú Phillips-görbe meredekségelecsökkent, ami azt jelenti, hogy nehezebben gyorsul az infláció, de sokkal költségesebb az infláció sebességének csökkentése is,

- bizonyos kulcsváltozók inflációra gyakorolt hatása megváltozott (a becsült rövid távú Phillips-görbe egyenletekben például többek között az olaj árának koefficiense is lecsökkent).

Mishkin (2007a) és Weber (2007) szerint ezek a változások a jobb minőségű monetáris politikának köszönhetők, de az irodalomban léteznek ettől eltérő magyarázatok is. Magyarázatot jelenthet például, ha a vállalatok árazási szokásai megváltoznak, erre példa Davig (2007), ahol az alacsony infláció miatt a vállalatok csökkentik az áremelések gyakoriságát - azaz e magyarázat szerint az alacsony infláció endogén jelenség. Rogoff (2003a, 2003b) rámutat arra, hogy az alacsony infláció ott is megfigyelhető, ahol semmi olyan más változás nem következett be, ami miatt jobb minőségüvé válhatna a monetáris politika (függetlenség, konzervatív jegybankár, hitelesség, átláthatóság stb.). Rogoff szerint az infláció elsősorban olyan külső tényezők miatt lett kisebb, mint az integráció okozta nagyobb verseny, ami csökkenti a helyi monopóliumok kialakulásának esélyét. Weber (2007) ezt azzal cáfolja, hogy a termékpiacok integrációja hamarabb kezdődött, mint az alacsony

15 Ebben a kérdésben valószínüleg érdekes, új viták várhatók az elmúlt időszak eseményeinek tükrében. 
infláció korszaka. ${ }^{16}$ Rogoff másik magyarázata szerint a nagyobb verseny (főleg a tőkepiacokon) mintegy a stabilitás külső elvárásaként ${ }^{17}$ növeli a nyomást a monetáris politikán az infláció csökkentésére. ${ }^{18}$ Ha pedig a megnövekedett verseny tényleg fokozza az árak rugalmasságát, akkor nincs is értelme az infláció gerjesztésének, hiszen monetáris expanziónak csak abban az esetben van pozitív reálgazdasági hatása, ha az árak ragadósak. Az infláció növelésére ösztönző tényezők hiánya viszont növeli a hitelességet (azaz könnyebbé válik az infláció csökkentése).

Másrészről a tőkéért folytatott fokozódó verseny miatt a fiskális politika is csak korlátozott mértékben képes deficitet termelni, ami megakadályozhatja az anticiklikus lépések megtételében. ${ }^{19} \mathrm{Ha}$ emellett az adóemelés lehetőségével is csak korlátozottabban élhet, akkor ez egy növekvő igényt jelenthet a seigniorage jövedelmek iránt, ami közvetlenül érinti a monetáris politika stabilizációs törekvéseit és a függetlenség megítélését.

Spiegel (2008) megpróbálja empirikusan ellenőrizni ezt a hipotézist, azaz, hogy a pénzügyi nyitottságnak valóban van-e fegyelmező ereje. A nyitottság mérőszámaként a Kose et al. (2006) által kialakított indexet használja, és annak endogenitása miatt a pénzügyi távolsággal (amit a legközelebbi pénzügyi központtól - London, New York, Tokió - vett távolsággal definiál) instrumentálja. Eredményei szerint nehéz a pénzügyi globalizáció hatását izolálni, mivel a nyitottság negatív hatása az átlagos inflációra nem robusztus a különböző specifikációk között.

Razin - Binyamini (2007) egy modellben ábrázolják a globalizáció jellemzőit:

- a megnövekedett nemzetközi kereskedelmet, specializációval a termelésben és diverzifikációval a fogyasztói kosárban,

- a migráció miatt a hazai bérek és hazai jövedelmek nem mindig mozognak együtt, mivel a hazai munkakínálatnak vannak külföldi helyettesítöi, és a hazai munkakínálat bérrugalmassága is nőhet, hiszen hazai foglalkoztatásnak is vannak alternatívái,

- a pénzügyi integráció pedig lehetővé teszi, hogy a háztartások simítsák a fogyasztásukat, ami csökkentheti a munkakínálat volatilitását.

Ezek együttes eredményeként gyengül a kapcsolat a hazai kibocsátás-fluktuáció és a hazai infláció között - a háztartások jóléte egyre kevésbé függ a hazai kibocsátástól, ahogy a gazdaság egyre jobban kinyílik. Minden nyitási fokozattal (csak a termékpiacok integráltak, a termék- és tőkepiacok is integráltak, minden piac integrálódott, beleértve a munkapiacot is) a Phillips-görbe egyre laposabbá válik, azaz ugyanaz a kibocsátási rés egyre kisebb inflációt generál.

Többen találtak empirikus bizonyítékot arra, hogy a Phillips-görbe laposabbá válik: példaként lehet említeni Williams (2006b)-t, akinek sikerült amerikai adatokon kimutatnia, hogy a kibocsátási rés kisebb hatással van az inflációra. Hasonló eredményeket ért el Borio - Filardo (2007), akik a fentieknek megfelelően két megközelítési módot különböztetnek

16 Weber (2007) ennél tovább megy, hiszen azt állítja, hogy a termékpiacokba újonnan integrálódott országok (különösen Kína és India) gyors iparosítása miatt az emelkedő kereslet áremelkedéseket, ezzel együtt inflációt okozhat. $A$ nagyobb integráció szerinte így veszélyezteti az árstabilitást.

17 Wagner (2002) szerint az alacsony és stabil infláció része a tőkét vonzani képes infrastruktúrának, míg Cukierman (2007) megmutatja, hogy az integrálódott tőkepiacok és a stabil makrokörnyezet iránti igény áll az egyre több országra jellemző jegybanki függetlenség mögött, amit a stabil politika melletti elköteleződésként is fel lehet fogni.

18 Wagner - Berger (2003) hasonló következtetésre jut: a vállalatok közötti verseny egyszeri árszínvonalesést eredményez, a kormányzatok közötti mobilis tőkéért folytatott verseny viszont folyamatos nyomást gyakorol az inflációra.

19 Többek között Cecchetti (2002) is hasonló következtetésre jut a fiskális politikával kapcsolatban. 
meg. Az egyik szerint az inflációt hazai tényezők (hazai kibocsátási rés, hazai foglalkoztatási rés) határozzák meg, a világgazdaság eseményeit egyedül az árfolyam és az importárak közvetítik, az áru- és munkapiac szegmentált, továbbá a hazai és külföldi termékek és munkaerő nem helyettesítik egymást. Ezzel szemben az infláció globális megközelítése hasonló feltevésekkel él, mint Razin - Binyamini (2007) modell feltevései, azaz a tőke és a tudás szabadon áramlik, a hazai és külföldi termékek és munkaerő tökéletes helyettesítői egymásnak, így a különböző termékeknél az árváltozások meghatározó tényezője a globális kibocsátási rés lesz (úgy is megfogalmazható, hogy nem termékeket aggregálunk országonként, hanem országokat aggregálunk termékenként). Ebben a megközelítésben a relatív árak és bérek adottak az országok számára, és a nemzetközi sokkok az exportpiacon és a külső keresleten keresztül is érintik az adott gazdaságot. A 16 fejlett országon tesztelt feltevés azt mutatta, hogy a hazai infláció egyre kevésbé érzékeny a hazai kibocsátási résre, miközben a külföldi kibocsátási rés szignifikánssá vált, és ez az eredmény olyan gyakran használt, sokkokat megjelenítő magyarázó változók beépítése után is robusztus, mint például az olajárak. Chmielewski - Kot (2006) Borio - Filardo (2007)-hoz hasonló egyenletet becsül a lengyel gazdaságra. Az eredményeik azt mutatják, hogy ha azokat a termékkategóriákat, amelyeknek kiterjedt nemzetközi kereskedelmük van (ruházat, lábbelik, telekommunikációs eszközök - a fogyasztói kosár összesen 6 \%-a), kihagyják a maginfláció számításához használt fogyasztói kosárból, akkor a maradék 66 \%-ra (az élelmiszerek és az energiahordózok hiányoznak a maginflációs megközelítés miatt) a hazai kibocsátási résnek továbbra is szignifikáns hatása van.

Ezek az eredmények azt sugallják, hogy az inflációnak van egy olyan része, ami kevésbé érzékeny a hazai monetáris politika által befolyásolható folyamatokra.

\section{A változások eredője}

Egy következtetést biztosan levonhatunk az eddigiekböl, nevezetesen, hogy a transzmiszsziós folyamatok még az eddigieknél is kiszámíthatatlanabbá váltak. ${ }^{20}$

Ezeket a bizonytalanságokat a következőképpen lehetne csoportosítani.

- Adat- és mérési bizonytalanság. Ez egyrészt abból származik, hogy a makroadatsorok csak bizonyos időbeli csúszással állnak rendelkezésre, ami nehezíti az elvben rájuk alapozott döntéshozatalt. Másrészt az is bizonytalanságot okozhat, hogy egyes kulcsváltozóknak nincs kiforrott definíciója és módszertana, ami megnehezíti az egységes kezelésüket (ilyen a potenciális kibocsátás és a munkanélküliség természetes rátája, amire minden kibocsátási rés kiszámításához szükség van ${ }^{21}$ ). Orphanides (2001) azzal magyarázza a 70-es évek laza monetáris politikáját az Egyesült Államokban, hogy a döntéshozók a rendelkezésre álló adatok alapján felülbecsülték a potenciális kibocsátást, és a monetáris expanziókkal oda kívánták visszajuttatni a gazdaságot. Szerinte részben ez a tévedés okozta az akkori a magas

20 Friedman hívta fel a figyelmet először a transzmisszió időbeli lefolyásának bizonytalanságaira híres cikkében (Friedman (1968).

21 Walsh (2003) ezért ajánlja, hogy a definíciós problémák elkerüléséhez a különböző politikai szabályokba inkább a kibocsátás növekedésének első differenciáját, azaz a növekedés sebességének változását építsék bele. Blinder (2006) azt ajánlja, hogy a potenciális kibocsátás helyett a munkanélküliség természetes rátája kerüljön a veszteségfüggvényekbe, hiszen a potenciális kibocsátás becsléséhez úgyis a munkanélküliség természetes rátájának becslésén keresztül vezet az út, így csökkenteni lehet a bizonytalanságot. 
inflációt.

- Bizonytalanság a sokkokban. A döntéshozó nem lehet biztos abban, hogy a bekövetkezett sokk átmeneti vagy pedig tartós, hiszen a monetáris politikának csak a tartós sokkokra kellene reagálnia.

- Modellbizonytalanság. A monetáris politika döntéshozói nem képesek naprakészen követni a gazdaság struktúrájának változásait, ebbe a kategóriába tartoznak azok a változások, amelyekkel az eddigiekben foglalkoztunk.

Williams (2006a), Orphanides - Williams (2002, 2007) a fenti bizonytalanságokra robusztus monetáris politikai szabály becslésével kísérleteznek. Eredményeik aszimmetrikusak abban az értelemben, hogy a bizonytalanság alulbecslése sokkal nagyobb veszteségeket okoz (kibocsátás- és inflációvolatilitásban mérve), mint a felülbecslése. Eredményeik összhangban vannak korábbi ajánlásokkal a bizonytalanság kezelésével kapcsolatban, még Brainard (1967) híres cikkét is lehet úgy értelmezni, ${ }^{22}$ hogy az összeadódó bizonytalanságok miatt a bizonyossági egyenértékes módszert nem lehet használni, így a monetáris politikai lépéseknek kisebbeknek, óvatosabbaknak és a fokozatosaknak kellene lenniük. Blinder (2006) ezt a fokozatosságot és óvatosságot emberi tényezőkkel is magyarázza, amely szerint a döntéshozók nem akarják kockáztatni a hitelességüket, és egy nagy lépést sok kicsivel helyettesítenek, ami lehetővé teszi, hogy adott esetben a lépések megfordítása helyett egyszerüen megálljanak a folyamat közben. ${ }^{23}$

A bizonytalanság növekedésén túl azt is érdemes megvizsgálni, hogy a különböző transzmissziócsatornákra miképpen hatottak a fenti folyamatok. A hatásokat aszerint csoportosíthatjuk, hogy melyik csatornára hatottak, és azon keresztül erősebbé vagy gyengébbé, gyorsabbá vagy lassúbbá tették a monetáris sokk hatását. Ezeket foglaltuk össze az 1. táblázatban.

\section{A különböző csatornák változásának várható hatása a monetáris politika transzmissziójának erejére és sebességére}

\begin{tabular}{|c|c|c|c|}
\hline \multirow{2}{*}{\multicolumn{2}{|c|}{$\begin{array}{l}\text { A különböző csatornák } \\
\text { változásának várható hatása } \\
\text { a monetáris transzmisszió }\end{array}$}} & \multicolumn{2}{|l|}{ Sebességére } \\
\hline & & Gyorsít & Lassít \\
\hline \multirow{2}{*}{ erejére } & erősít & $\begin{array}{l}\text { kamatcsatorna (Sukudhew et } \\
\text { al. 2008) }\end{array}$ & $\begin{array}{l}\text { vagyonon keresztül ható } \\
\text { csatornák (Mylonas et al. } \\
\text { 2000) }\end{array}$ \\
\hline & gyengít & $\begin{array}{l}\text { hitelezési csatornák (Bernanke } \\
\text { 2007) } \\
\text { árfolyamcsatorna }\end{array}$ & \\
\hline
\end{tabular}

A kamatcsatornát a liberalizáció és a dereguláció feltételezhetően erősítette, ezért a bankok áttértek a mennyiségi korlátozásról az ármeghatározásra, ami egyben azt is jelenti, hogy

22 Lásd Blinder (2006) és Walsh (2003).

23 Ha a Fed elkezd kamatot emelni vagy csökkenteni, akkor az elkövetkező két évben kis lépésekben átlagosan 3,75 százalékpontot mozdul el adott irányba az irányadó kamatláb (lásd Jorda 2005 cikkét arról, hogy miként hat ez a megfigyelés az amerikai hozamgörbére). 
már maguk az ügyfelek is az árak (kamatok) megváltozására reagálnak, így nem az elérhető mennyiség szab határt a keresletnek. A dezintermediáció önmagában is erősítheti az aggregált kereslet reakcióját a kamatváltozásra, ha ennek következtében a gazdaság szereplöi kamatérzékenyebb eszközöket tartanak a vagyonmérlegükben (Sukudhew et al. 2008). Ezt az érvelést gyengíti, hogy a monetáris politika hatása gyengül a hosszú távú kamatlábak esetében, amelyek ténylegesen befolyásolhatják ezt a viselkedést.

Mylonas et al. (2000) és Sukudhew et al. (2008) szerint a pénzügyi integráció következtében megnövekedett pénzügyi eszközállomány erősíteni fogja a gazdaság szereplöinek reakcióját az eszközök átértékelésére, emiatt megnövekedhet a vagyoncsatorna súlya. Egyúttal lassítaná is a reakciót, hiszen bizonyos vagyonelemek átértékelődése hosszabb időt vehet igénybe (ingatlanok), ami elnyújthatja például a háztartások reakcióját.

A tőkepiacok integrációja és növekedése szélesebb körben teszi lehetővé a vállalatok számára a banki hitelek helyettesítését. Ez már önmagában gyengítheti a hitelcsatornák jelentőségét. Ezen túl, ahogy már korábban szó volt róla, a pénzügyi közvetítő rendszer integrációja megnövelte az átlagos bankméretet, továbbá a pénzügyi innovációk (értékpapírosítás) lehetővé teszik, hogy a bankok tartalékolás nélkül hitelezzenek, ami tovább gyengíti a hitelezési csatorna addicionális hatását. Ha pedig az új technológiai lehetőségek ténylegesen elősegítik az aszimmetrikus információs problémák megoldását (ahogy azt Mishkin - Strahan 1999 állítja), akkor a biztosítékok szerepe is csökkenhet, ami a mérleghatás erejét gyengíti. Összességében ez lehet az oka annak a következtetésnek, amit Bernanke (2007) irodalmi összefoglalója alapján levon, miszerint egyre nehezebb empirikusan kimutatni a hitelcsatornát az Egyesült Âllamokban.

$\mathrm{Az}$ árfolyamcsatorna megváltozása azért került a transzmissziót gyengítő hatások közé, mert az integráció lehetővé tette a vállalatoknak és háztartásoknak, hogy külföldi eszközöket tartsanak és devizában adósodjanak el. Főleg az utóbbi gyengítheti a monetáris politika transzmissziójának jövedelmi és vagyonhatását, szélsőséges esetben akár meg is fordíthatja azt, hiszen egy kamatcsökkentés leértékelve az árfolyamot átértékeli az adósságot, és ezzel megemeli a törlesztőrészletek hazai pénzben mért értékét, csökkentve a rendelkezésre álló jövedelmet, a fogyasztást és a beruházásokat.

A várakozási csatorna kimaradt az 1. táblázatból, mivel endogén, hiszen az árstabilitás melletti hiteles elkötelezettségen túl a várakozások attól is függnek, hogy miképpen tudja a monetáris politika befolyásolni a kibocsátást és az inflációt. Azaz a várakozási csatorna függ a fenti hatások eredőjétől.

Az elméleti megfontolások idáig vezetnek, így az eredő meghatározása jelen esetben elmarad, hiszen nem lehet elméleti alapon megmondani, hogy a különböző csatornák egymáshoz képest milyen módon fogják befolyásolni a monetáris politika transzmiszszióját, figyelembe véve azt is, hogy a válasz valószínüleg országonként is eltérö. A jövőben empirikus vizsgálatok segítségével lehetne választ adni a relatív változásokra.

\section{Összefoglalás}

A technológiai környezet megváltozása és a fokozódó integráció sok gazdasági összefüggésre hatást gyakorolt. A kérdés - amit a tanulmány során körbejártunk - arra vonatkozott, hogy ezek a folyamatok hogyan befolyásolják a monetáris politika transzmiszszióját. Az irodalom áttekintése után arra az eredményre jutottunk, hogy ezt az egyébként 
nagyon összetett kapcsolatot még a korábbiaknál is kiszámíthatatlanabbá teszi az integráció fokozódása, valószínűleg erősítve a kamatláb- és vagyonhatásokat, gyengítve a hitelcsatornát és árfolyamcsatornát, különösen, ha a devizahitelek vagy carry trade szerepe is jelentős.

Ahogy a korábbiakban már jeleztem, a kvalitatív eredmények után következhet a kvantitatív vizsgálat, azaz empirikus úton választ keresni arra a kérdésre, hogy a különböző transzmissziós csatornák megváltozása és a fokozódó bizonytalanság összességében milyen hatást gyakorolnak a monetáris politikára.

\section{Hivatkozások}

Bernanke, B. (2005): Monetary Policy in a World of Mobile Capital. CATO Journal, 25. évf., 1. sz. 1-12.

Bernanke, B. (2007): Financial Accelerator and the Credit Channel. The Credit Channel of Monetary Policy in the Twenty-first Century konferencián tartott beszéd, Federal Reserve Bank of Atlanta, Atlanta, június 15. letöltve: 2008. 09. 29. 9:00 http://www.bis.org/review/r070621a.pdf.

Bernanke, B. - Gertler, M. (1995): Inside the Black Box: The Credit Channel of Monetary Policy Transmission. The Journal of Economic Perspective, 9. évf. 4 sz. ösz, 27-48.

Bernanke, B. - Gertler, M. (1999): Monetary Policy and Asset Price Volatility. „New Challenges for Monetary Policy" konferencián tartott elöadás, Federal Reserve Bank of Kansas City, augusztus 26-28. letöltve: 2008. 09. 29. 9:00 http://www.kc.frb.org/Publicat/sympos/1999/sym99prg.htm.

Blinder, A. S. (2000): Critical Issues for Modern Central Bankers. Megjelent: ECB (2000): Monetary Policy under Uncertainty. European Central Bank, 64-74.

Blinder, A. S. (2006): Monetary Policy Today: Sixteen Question and about Twelve Answers. „Central Banks in the $21^{\text {th }}$ century" konferencián tartott elöadás, Banco de España, Madrid, június 8-9.

Bollard, A. (2007): Easy money - global liquidity and its impact on New Zealand. Wellington Chamber of Commerce előtt tartott beszéd, március 15. letöltve: 2008. 09. 29. 9:00 http://www.bis.org/review/ r070315a.pdf.

Bordo, M. D. - Eichengreen, B. - Irwin, D. A. (1999): Is Globalization Today Really Different Than Globalization a Hundred Years Ago? National Bureau of Economic Research, NBER Working Paper Series, Working Paper 7196. sz., június.

Borio, C. - Filardo, A. (2007): Globalistion and inflation: new cross-country evidence on the global determinants of domestic inflation. Bank of International Settlements, Monetary and Economic Department, BIS Working Paper Series, Working Paper 227. sz., május.

Brainard, W. C. (1967): Uncertainty and the Effectiveness of Policy. The American Economic Review, 57. évf. 2. sz., Papers and Proceedings of the Seventy-ninth Annual Meeting of the American Economic Association, május, 411-425.

Briault, C. (1995): The costs of inflation. Bank of England, Quarterly Bulletin, 35. évf. 1. sz., február, $33-45$.

Cecchetti, S. G. (2002): The New Economy and the Challenges for Macroeconomic Policy. National Bureau of Economic Research, NBER Working Paper Series, Working Paper 8935. sz., május.

Chmielewski, T. - Kot, A. (2006): Impact of globalisation? Changes in the MTM in Poland. Munich Personal RePec Archive, MPRA Paper 8386. sz., szeptember.

Cukierman, A. (2007): Central Bank Independence and Monetary Policymaking Institutions - Past Present and Future. Centre for Economic Policy Research, Discussion Paper Series, DP 6441. sz., szeptember.

Davig, T. (2007): Phillips Curve Instability and Optimal Monetary Policy. Federal Reserve Bank of Kansas City, Economic Research Department, Research Workig Papers 07-04. sz., július.

Ehrmann, M. - Fratzscher, M. (2006): Global Financial Transmission of Monetary Policy Shocks. European Central Bank, Working Paper Series, Working Paper 616. sz., április.

English, W. B. (1999): Inflation and financial sector size. Journal of Monetary Economics, 44. évf. 3. sz., december, 379-400. 
Feldstein, M. (2005): Monetary Policy in a Changing International Environment: the Role of Capital Flows? National Bureau of Economic Research, Working Paper Series, Working Paper 11856. sz., december.

Feldstein, M. - Horioka, Ch. (1980): Domestic Savings and International Capital Flows. The Economic Journal, 90. évf. 358. sz., június, 314-329.

Freedman, Ch. (2000): Monetary Policy Implementation: Past, Present and Future - Will the Advent of Electronic Money Lead to the Demise of Central Banking? International Finance, 3. évf. 2. sz., július), 211-227.

Friedman, B. M. (1999): The Future of Monetary Policy: The Central Bank as An Army With Only A Single Corps? National Bureau of Economic Papers, NBER Working Paper Series, Working Paper 7420. sz., november.

Friedman, B. M. (2000): Decoupling at the Margin: The Threat to Monetary Policy from the Electronic Revolution in Banking. International Finance, 3. évf. 2. sz., július, 261-272.

Friedman, M. (1968): The Role of Monetary Policy. The American Economic Review, 58. évf. 1. sz., március, $1-17$.

Genberg, H. (2008): The changing nature of financial intermediation and its implications for monetary policy. Megjelent: BIS (2008): Financial market developments and their implications for monetary policy. Bank for International Settlements, BIS Papers 39. sz., április, BIS és a Bank Negara Malaysia által közösen Kuala Lumpurban szervezett 2007. augusztus 17-ei konferencia tanulmányai, 100-119.

Gudmundsson, M. (2008): Financial globalization: key trends and implications for the transmission mechanism of monetary policy. Megjelent: BIS (2008): Financial market developments and their implications for monetary policy. Bank for International Settlements, BIS Papers 39. sz., április, BIS és a Bank Negara Malaysia által közösen Kuala Lumpurban szervezett 2007. augusztus 17-ei konferencia tanulmányai, 7-29.

Haydar, A. - Seyfettin, A. (2006): The reflections of new economy on monetary policy and central banking. Munich Personal RePEc Archive, MPRA Paper 603. sz., október, letöltve: 2007.05.15. 18:30, http:// mpra.ub.uni-muenchen.de/603.

Issing, O. - Gaspar, V. - Tristani, O. - Vestin, D. (2005): Imperfect knowledge and Monetary Policy. The Stone Lectures in Economics, Cambridge University Press, Cambridge.

Jordà, Ò. (2005): Can Monetary Policy Influence Long-term Interest Rate? Federal Reserve Bank of San Francisco, FRBSF Economic Letter 2005-09. sz., május 20. 1-3.

Kose, M. A. - Prasad, E. - Rogoff, K. - Wei, Sh. J. (2006): Financial Globalization:a Reappraisal. National Bureau of Economic Research, NBER Working Paper Series, Working Paper 12484. sz., augusztus.

Mishkin, F. S. (1996): The channels of monetary transmission: lessons for monetary policy. National Bureau of Economic Research, NBER Working Paper Series, Working Paper 5464. sz., február.

Mishkin, F. S. (2000): What Should Central Bank Do? Federal Reserve Bank of St. Louis, Review, novemberdecember, 1-14.

Mishkin, F. S. (2007a): Inflation Dynamics. National Bueau of Economic Research, NBER Working Paper Series, Working Paper, 13147. sz., június.

Mishkin, F. S. (2007b): Will Monetary Policy Become More of a Science? National Brueau of Economic Research, NBER Working Paper Series, Working Paper 13566. sz., október.

Mishkin, F. S. - Strahan, Ph. E. (1999): What will technology do to financial structure? National Bureau of Economic Research, NBER Working Paper Series, Working Paper 6892. sz., január.

Mylonas, P.- Stich, S. - Wehinger, G. (2000): Monetary Policy in a Changing Financial Environment. Organisation of Economic Co-operation and Development, Economics Dapertment, Working Paper Series, ECO-WKP 243. sz., május 18.

Obstfeld, M. - Taylor, A. M. (2002): Globalization and Capital Markets. National Bureau of Economic Research, Working Paper Series, Working Paper 8846. sz., március.

Orphanides, A. (2001): Monetary Policy Rules, Macroeconomic Stability and Inflation: a View from the Trenches. European Central Bank, ECB Working Paper Series, Working Paper 115. sz., december.

Orphanides, A. - Williams, J. C. (2002): Robust Monetary Policy Rules with Unknown Natural Rates. Brookings Papers on Economic Activity, 2002. évf. 2. sz., 63-118.

Orphanides, A. - Williams, J. C. (2007): Robust Monetary Policy with Imperfect Knowledge. Journal of Monetary Economics, 54. évf. 5. sz., július, 1406-1435. 
Razin, A. - Binyamini, A. (2007): Flattened Inflation-Output Tradeoff and Enhanced Anti Inflation Policy: Outcome of Globalization? National Bureau of Economic Research, NBER Working Paper Series, Working Paper 13280. sz., július.

Rogoff, K. S. (2003a): Disinflation: An Unsung Benefit of Globalization? Finance and Development, 40. évf. 4. sz., december, 54-55.

Rogoff, K. S. (2003b): Globalization and Global Disinflation. "Monetary Policy and Uncertainty: Adapting to a Changing Economy" konferencián tartott előadás. Federal Reserve Bank of Kansas City, Jackson Hole, WY, augusztus 29. letöltve: 2007. 11. 10. 9:00 http://www.kc.frb.org/publicat/sympos/2003/ sym03prg.htm.

Spiegel, M. M. (2008): Financial Globalization and Monetary Policy Discipline: A Survey with New Evidence From Financial Remoteness. Federal Reserve Bank of San Francisco, Working Paper Series, Working Paper, 10. sz., július.

Stock, J. H. - Watson, M. W. (2003): Has the Cycle Changed? Evidence and Explanation. Federal „Monetary Policy and Uncertainty: Adapting to a Changing Economy" konferencián tartott előadás. Federal Reserve Bank of Kansas City, Jackson Hole, WY, augusztus 29. letöltve: 2007. 11. 10. 9:00. http:// www.kc.frb.org/publicat/sympos/2003/sym03prg.htm.

Sukudhew, S. - Rozi, A. - Endut, N. - Ramlee, H. (2008): Impact of financial developments on the monetary transmission mechanism. Megjelent: BIS (2008): Financial market developments and their implications for monetary policy. Bank for International Settlements, BIS Papers 39. sz., április, BIS és a Bank Negara Malaysia által közösen Kuala Lumpurban szervezett 2007. augusztus 17-ei konferencia tanulmányai, 49-99.

Taylor, J. B. (1993): Discretion versus policy rules in practice. Carnegie-Rochester Conference Series on Public Policy, 39. évf., december, 195-214.

Taylor, J. B. (1995): The Monetary Transmission Mechanism: An Empirical Framework. The Journal of Economic Perspective, 9. évf. 4. sz., ősz, 11-26.

Tobin, J. (1969): A general equilibrium approach to monetary theory. Journal of Money, Credit and Banking, 1. évf. 1. sz. (1969. február), 15-29.

Wagner, H. (2002): Implication of Globalization for Monetary Policy. Société Universitaure Européenne de Recherches Financiéres, SUERF Studies 17. sz., Bécs.

Wagner, H. - Berger, W. (2003): Financial Globalization and Monetary Policy. De Nederlandsche Bank, DNB Staff Reports 95/2003. sz.

Walsh, C. E. (2003): Implication of a Changing Economic Structure for the Strategy of Monetary Policy. "Monetary Policy and Uncertainty: Adapting to a Changing Economy" konferencián tartott elöadás. Federal Reserve Bank of Kansas City, Jackson Hole, WY, 2003. augusztus 29. letöltve: 2007. 11. 10. 9:00 http://www.kc.frb.org/publicat/sympos/2003/sym03prg.htm.

Weber, A. A. (2007): Challenges posed by (financial) globalisation. Elöadás a Punei Egyetemen, Pune 2007. március 15., letöltve: 2008. 09. 29. 9:00 http://www.bis.org/review/r070330b.pdf.

Williams, J. C. (2006a): Robust Estimation and Monetary Policy with Unobserved Structural Change. Federal Reserve Bank of San Francisco, Economic Review, 1-16.

Williams, J. C. (2006b): The Phillips Curve in an Era of Well-Anchord Inflation Expectation. Federal Reserve Bank of San Fransisco, FRBSF Economic Letter, 27. sz., október 13. 1-4. 